\title{
MicroRNA-21-5p protects melanocytes via targeting STAT3 and modulating Treg/Teff balance to alleviate vitiligo
}

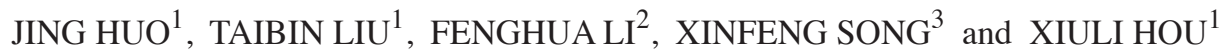 \\ Departments of ${ }^{1}$ Dermatology and ${ }^{2}$ Endocrinology, Dezhou People's Hospital, Dezhou, Shandong 253014; \\ ${ }^{3}$ Pathology Laboratory, Dezhou College, Dezhou, Shandong 253000, P.R. China
}

Received Februrary 26, 2020; Accepted June 5, 2020

DOI: $10.3892 / \mathrm{mmr} .2020 .11689$

\begin{abstract}
Vitiligo (VIT) is caused by loss and degradation of functional epidermal melanocytes. Studies have indicated that melanocyte destruction may be associated with an imbalance between regulatory $\mathrm{T}$ cells (Treg cells) and effector $\mathrm{T}$ cells (Teff cells). The current study aimed to investigate the molecular mechanism through which Treg/Teff balance affects VIT pathogenesis. To explore this, peripheral blood mononuclear cells were isolated from patients with VIT and healthy individuals. The present study revealed that the proportions of $\mathrm{CD}^{+} \mathrm{T}$ cells, Treg cells and T helper 1 (Th1) cells were decreased in patients with VIT, but those of Teff cells (Th17 and Th22 cells) were increased; additionally, Foxp3 expression was decreased, but the expression levels of interferon- $\gamma$, interleukin (IL)-17A and IL-22 were increased. Furthermore, in patients with VIT, microRNA (miR)-21-5p expression was decreased, while that of STAT3 was increased. Further in vitro experiments in $\mathrm{CD} 4^{+} \mathrm{T}$ cells revealed that STAT3 was targeted by miR-21-5p. Functional analysis further indicated that miR-21-5p overexpression in Th17-polarized CD4 ${ }^{+} \mathrm{T}$ cells decreased the proportion of Teff cells and associated cytokines, such as IL-17A and IL-22, but increased the proportion of Treg cells and Foxp3. However, the effects of miR-21-5p overexpression were partly reversed by STAT3 overexpression. Increased apoptosis of melanocytes was detected after co-culture with Th17-polarized CD4 ${ }^{+} \mathrm{T}$ cells in the presence of a miR-21-5p mimic. However, this indirect effect of the miR-21-5p mimic on melanocytes was decreased via STAT3 overexpression. Therefore, miR-21-5p may protect melanocytes via targeting STAT3 and regulating Treg/Teff balance. The current findings may provide a possible treatment method for managing VIT.
\end{abstract}

Correspondence to: Dr Xiuli Hou, Department of Dermatology, Dezhou People's Hospital, 1166 Dongfanghong West Road, Decheng, Dezhou, Shandong 253014, P.R. China

E-mail: xiuli_houx@163.com

Key words: microRNA-21-5p, melanocytes, Treg/Teff balance, vitiligo, STAT3

\section{Introduction}

Vitiligo (leukoderma, VIT) is characterized by pigment loss in skin patches and is defined as a long-term skin condition in which patches of affected skin turn white with obvious color margins (1). The disease incidence was $0.5-2 \%$ worldwide in 2017, independently of sex or ethnicity factors (2). There is increasing evidence that loss and degradation of functional epidermal melanocytes may cause the onset of VIT $(2,3)$. It has been speculated that autoimmunity, cytotoxic metabolites and oxidative stress induction may be the factors causing VIT development and progression (4), and therefore, may explain the molecular mechanisms underlying the degradation of melanocytes. However, the pathogenesis of VIT requires further investigation.

Melanocytes are melanin-producing neural crest-derived cells (5). Recent studies have demonstrated that VIT is an autoimmune disease that targets melanocytes and that melanin loss is the main cause of morbidity, regardless of ethnicity (6). Therefore, protecting melanocytes from being targeted may have potential for slowing down the development and progression of VIT (7).

Melanocytes may be targeted or destroyed by T-cellmediated immune responses initiated by autoimmune diseases (8). Effector T cells (Teff cells), mainly T helper 1 (Th1) and Th17 cells, are pro-inflammatory T cells that may induce the development and progression of autoimmune processes, while regulatory $\mathrm{T}$ cells (Treg cells) serve protective and anti-inflammatory roles (9) and are downregulated in autoimmune diseases (10). In multiple diseases, including skin diseases, an imbalance between Treg and Teff cells is detected, as Treg cells are decreased and Teff cells are increased (11). Additionally, a study has demonstrated that microRNAs (miRNAs/miRs) serve key roles in regulating the balance between Treg and Teff cells (12). However, the detailed molecular mechanisms remain unclear.

At present, miRNAs have been reported to have critical functions in the development and progression of VIT $(13,14)$. Overexpression of pre-miR-21 has been demonstrated to regulate Treg/Teff balance following gastric cancer resection (15). Another study revealed that low miR-21-5p expression was associated with an imbalance of Treg/Teff cells in patients with rheumatoid arthritis (16). Therefore, the present study hypothesized that miR-21-5p (also known 
as miR-21) may be a crucial regulator during the differentiation of Treg/Teff cells, which is rarely reported in VIT. Additionally, the mechanism through which miR-21-5p participates in VIT affecting the differentiation of Treg/Teff cells remains unclear. A study on the analysis of the miRNA signature in Treg cells indicated that miR-21 is highly expressed in Treg cells and positively regulates FOXP3 expression (17), which is considered to be a main regulator of Treg development. It is well known that the transcription of miR-21 can be activated by STAT3 signaling (18). However, in the present study, TargetScan 7.2 (targetscan.org) predicted that STAT3 may be a potential target of miR-21-5p.

Therefore, the present study aimed to investigate the role of miR-21-5p and its underlying mechanism associated with STAT3 in Treg/Teff balance, and its potentially indirect effect on melanocytes, hoping to find a potential therapeutic treatment for VIT.

\section{Materials and methods}

Ethics statement. The present study was approved by the Ethics Committee of Dezhou People's Hospital (approval no. PFK20181006; Dezhou, China). All participants provided written informed consent.

Isolation of peripheral blood mononuclear cells (PBMCs). PBMCs were isolated using Ficoll-Hypaque-based density gradient centrifugation (19). Peripheral blood samples were obtained from 15 patients with VIT and 15 healthy individuals and stored at $4^{\circ} \mathrm{C}$ to minimize cell activation. Whole blood samples were mixed with PBS (Biologos, LLC) and manually layered over a lymphocyte separation medium (Thomas Scientific), and centrifuged at 2,000 x g for $30 \mathrm{~min}$ at room temperature. The layer containing PBMCs was carefully harvested and then washed twice with PBS. The cells were resuspended in PBS and were counted manually using a Neubauer chamber (Ningbo Finer Medical Instruments Co., Ltd.) and light microscope (magnification, x100).

Flow cytometry. For analysis of lymphocyte subsets, PBMCs (1x10 ${ }^{6}$ cells/well) obtained from patients with VIT or healthy individuals were suspended in RPMI-1640 medium supplemented with 10\% FBS (Invitrogen; Thermo Fisher Scientific, Inc.), $25 \mathrm{ng} / \mathrm{ml}$ phorbol myristate acetate, $1 \mu \mathrm{g} / \mathrm{ml}$ ionomycin and $1 \mu \mathrm{g} / \mathrm{ml}$ brefeldin $\mathrm{A}$ at $37^{\circ} \mathrm{C}$ with $5 \% \mathrm{CO}_{2}$ for $5 \mathrm{~h}$. All data were analyzed by FlowJo software (version 7.6.1; FlowJo LLC).

Subsequently, cells were incubated and stained with the following PE-Cyanine5-conjugated monoclonal antibodies (mAbs): Anti-CD4 (RPA-T4; 1:40; cat. no. 15-0049-42), anti-CD8 (3B5; 1:500; cat. no. MHCD0818), anti-CD25 (PC61.5; 1:100; cat. no. 61-0251-82), anti-CD127 (A7R34; 1:700; cat. no. 15-1271-82), anti-interferon (IFN)- $\gamma$ (R4-6A2; Biotin; 1:400; cat. no. 36-7312-85), anti-interleukin (IL)-17 (50104; 1:100; cat. no. MA5-23748) and anti-IL-22 (22URTI; 1:500; cat. no. 12-7229-41) at $4^{\circ} \mathrm{C}$ for $10 \mathrm{~min}$; all antibodies were purchased from Thermo Fisher Scientific, Inc., and the experiments were performed according to the manufacturer's protocol. The lymphocyte subsets were then analyzed by flow cytometry. Differences in the

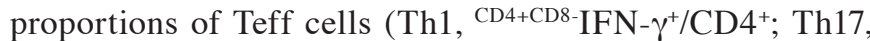
$\mathrm{CD}^{+}{ }^{+} \mathrm{CD} 8-\mathrm{IL}^{-17^{+}} / \mathrm{CD}^{+}{ }^{+}$; Th22, $\mathrm{CD} 4{ }^{+} \mathrm{CD} 8-\mathrm{IL}-22^{+} / \mathrm{CD}^{+}$) and Treg cells $\left(\mathrm{CD} 4^{+} \mathrm{CD} 25^{+} \mathrm{CD} 127^{-} / \mathrm{CD}^{+}\right)$in patients with VIT and in healthy controls were detected and measured using a CytoFLEX Flow Cytometry assay (B96622; Beckman Coulter, Inc.).

Cell apoptosis was detected using an Annexin V-fluorescein isothiocyanate/propidium iodide (PI) apoptosis kit (cat. no. K101; BioVision, Inc.) according to the manufacturer's protocol. Briefly, the cells were harvested $48 \mathrm{~h}$ after transfection, washed twice with cold PBS and treated with Annexin V and PI together for $15 \mathrm{~min}$ at room temperature in the dark. Cell apoptosis was detected using a flow cytometry assay (APO006; FLISP Serine Protease Detection kit; Bio-Rad Laboratories, Inc.). The Annexin $\mathrm{V}^{+} \mathrm{PI}^{+}$cells were considered to be the apoptotic cells. The apoptosis rate was assessed according to the proportion of Annexin $\mathrm{V}^{+} \mathrm{PI}^{+}$cells.

Enzyme-linked immunosorbent assay (ELISA). ELISA was performed to measure the protein expression levels of cellular cytokines (IFN- $\gamma$, IL-17A and IL-22) in the peripheral blood of patients with VIT and of healthy individuals, or from $\mathrm{CD} 4^{+} \mathrm{T}$ cells or melanocyte supernatant. The PBMCs and supernatant were separated by centrifugation at $2,000 \mathrm{x} \mathrm{g}$ for $15 \mathrm{~min}$ at $4^{\circ} \mathrm{C}$ and stored in aliquots at $80^{\circ} \mathrm{C}$. The expression levels of inflammatory factors (IFN- $\gamma$, IL-17A and IL-22) in CD4 ${ }^{+} \mathrm{T}$ cells or melanocyte supernatant were determined using their corresponding ELISA kits (cat. nos. KHC4021 for IFN- $\gamma$, BMS2017 for IL-17A and BMS2047 for IL-22; Invitrogen; Thermo Fisher Scientific, Inc.). OD values were detected and measured using a Crocodile 4-in-one assay miniWorkstation (Titertek-Berthold).

$R N A$ isolation and reverse transcription-quantitative (RT-q) $P C R$. Total RNA was extracted from PBMCs from patients with VIT or healthy controls using TRIzol ${ }^{\circledR}$ reagent (Invitrogen; Thermo Fisher Scientific, Inc.) and preserved at 4 or $-80^{\circ} \mathrm{C}$. The RNA preserved at $4^{\circ} \mathrm{C}$ was used for cDNA, while the RNA kept at $-80^{\circ} \mathrm{C}$ was for long-term storage. The concentration of total RNA was detected using a biological spectrometer (NanoDrop 2000; Thermo Fisher Scientific, Inc.). A total of $1 \mu \mathrm{g}$ of total RNA was reverse transcribed into cDNA at $37^{\circ} \mathrm{C}$ for $60 \mathrm{~min}$ and $4^{\circ} \mathrm{C}$ for 5 min using a First-strand cDNA Synthesis kit (cat. no. E6300L; New England BioLabs, Inc.) according to the manufacturer's protocol. RT-qPCR was conducted using the SYBR PremixEx Taq II kit (cat. no. RR820L; Takara Bio, Inc.) in an AriaMx real-time PCR system (cat. no. G8830A; Agilent Technologies, Inc.). Samples were run using the following thermocycling parameters: Initial denaturation at $95^{\circ} \mathrm{C}$ for $15 \mathrm{~min}$, $94^{\circ} \mathrm{C}$ for $15 \mathrm{sec}$, followed by 40 cycles of $60^{\circ} \mathrm{C}$ for $30 \mathrm{sec}$ and final extension at $72^{\circ} \mathrm{C}$ for $30 \mathrm{sec}$. Primer sequences are shown in Table I. GAPDH (for STAT3) and U6 (for miR-21-5p) were used as internal references. The relative expression levels of genes were quantified using the $2^{-\Delta \Delta \mathrm{Cq}}$ method (20).

Western blot analysis. Western blot analysis was performed to measure the protein levels of relative mRNAs in PBMCs from patients with VIT or healthy controls as previously described (21). Proteins were lysed and extracted using RIPA buffer (P0013C; Beyotime Institute of Biotechnology) shortly 
Table I. Primers used for reverse transcription-quantitative PCR.

\begin{tabular}{ll}
\hline Gene & \multicolumn{1}{c}{ Primers $\left(5^{\prime} \rightarrow 3^{\prime}\right)$} \\
\hline $\begin{array}{l}\text { Foxp3 } \\
\text { Forward } \\
\text { Reverse }\end{array}$ & GAGAAGCTGAGTGCCATGC \\
MicroRNA-21-5p & TGCCTTGTCGGATGATG \\
Forward & TGTTGAGTCGTATCCAGTGCAA \\
Reverse & GTATCCAGTGCGTGTCGTGG \\
STAT3 & \\
Forward & GAGGACTGAGCATCGAGCA \\
Reverse & CATGTGATCTGACACCCTGAA \\
U6 & \\
Forward & GAGAAAGTTAGCACGGCTTCTG \\
Reverse & CAAAATATGGAATGCTTCAAAGAG \\
GAPDH & \\
Forward & GATCAACACGTACCAGTGCAA \\
Reverse & CGCCTGTACACTCCACCAC \\
\hline
\end{tabular}

after cell collection, and protein concentration was measured using a BCA protein kit (Sigma-Aldrich; Merck KGaA). A total of $30 \mu \mathrm{g}$ protein/lane was separated via $12 \%$ SDS-PAGE (cat. no. P0012A; Beyotime Institute of Biotechnology) and transferred onto polyvinylidene fluoride membranes (cat. no. FFP28; Beyotime Institute of Biotechnology), which were then blocked using $5 \%$ skimmed milk for $2 \mathrm{~h}$ at room temperature. The membranes were incubated at $4^{\circ} \mathrm{C}$ overnight with the following primary antibodies: Anti-STAT3 antibody (mouse; 1:5,000; cat. no. ab119352; Abcam) and anti-GAPDH antibody (rabbit; 1:10,000; cat. no. ab181602; Abcam). GAPDH was used as the internal reference. The membranes were subsequently incubated at room temperature for $1 \mathrm{~h}$ with secondary horseradish peroxidase-conjugated antibodies: goat anti-mouse IgG H\&L (1:2,000; cat. no. ab205719; Abcam) and goat anti-rabbit IgG H\&L (1:2,000; cat. no. ab205718; Abcam). The membranes were washed three times with TBST $(0.1 \%$ Tween-20) and developed using an enhanced chemiluminescence kit (EMD Millipore). The grey values of the strips were quantified by ImageJ (version 5.0; National Institutes of Health).

Th17 cell polarization. PBMCs were isolated from patients with VIT using Ficoll-Hypaque-based density gradient centrifugation. $\mathrm{CD}^{+} \mathrm{T}$ cells used in the experiments were purified using CD4 microbeads (cat. no. 130-045-101; Miltenyi Biotec, Inc.) for PBMCs in peripheral blood with $95 \%$ purity. To induce Th17 cell polarization, $\mathrm{CD}^{+}{ }^{+} \mathrm{T}$ cells were cultured with $5 \mu \mathrm{g} / \mathrm{ml}$ anti-CD3 mAb (cat. no. 17-0038-42; Thermo Fisher Scientific, Inc.) in 24-well culture plates, and anti-CD28 mAb (cat. no. CD2804; Thermo Fisher Scientific, Inc.) at a final concentration of $2 \mu \mathrm{g} / \mu \mathrm{l}$ and incubated in RPMI-1640 medium (Thermo Fisher Scientific, Inc.) at $4^{\circ} \mathrm{C}$ for $30 \mathrm{~min} 5 \% \mathrm{CO}_{2}$. Cell were treated with $5 \mathrm{ng} / \mathrm{ml}$ tumor growth factor (TGF)- $\beta$, $20 \mathrm{ng} / \mathrm{ml} \mathrm{IL-6}$ and $25 \mathrm{ng} / \mathrm{ml} \mathrm{IL-23}$ to induce the polarization of Th17 cells at $4^{\circ} \mathrm{C}$ for $30 \mathrm{~min}$.
Target prediction and Dual-Luciferase reporter assay. Target gene and potential binding sites of miR-21-5p and STAT3 were predicted using TargetScan 7.2 (targetscan.org), and subsequently confirmed via Dual-Luciferase reporter assay.

A PMIR-REPORT Luciferase vector (cat. no. AM5795; Thermo Fisher Scientific, Inc.) containing wild-type (WT) or mutated (MUT) STAT3 sequences was cloned into the pMirGLO reporter vector (Promega Corporation) to generate STAT3-WT and STAT3-MUT, respectively. CD4 ${ }^{+} \mathrm{T}$ cells $\left(5 \times 10^{3}\right.$ cells/well $)$ from 1 normal control were cultured in 96-well plates and co-transfected with STAT3-WT (sequence, 5'-ACUCUUCAGUACAUAAUAAGCUU-3') or STAT3-MUT (sequence, 5'-ACUCUUCAGUACAUAGGC CAUGU-3'), and a miR-21-5p mimic or a mimic control using Lipofectamine ${ }^{\circledR} 3000$ (Thermo Fisher Scientific, Inc.) according to the manufacturer's protocol at $37^{\circ} \mathrm{C}$. The Renilla luciferase gene of the pMirGLO reporter vector served as an internal control. Cells were harvested $48 \mathrm{~h}$ after transfection for the detection of luciferase activity using a dual-luciferase reporter assay (cat. no. E1910; Promega Corporation) according to the manufacturer's protocol. Firefly luciferase activity was normalized to Renilla luciferase activity.

Cell co-culture and transfection. For cell co-culture, Th17-polarized CD4 ${ }^{+} \mathrm{T}$ cells obtained from patient with VIT were cultured in the upper chamber, whereas primary melanocytes were cultured in the lower chamber. Cells were cultured in $0.4 \mu \mathrm{M}$ Transwell inserts for 24-well plates (Greiner Bio-One International $\mathrm{GmbH}$ ) at $37^{\circ} \mathrm{C}$ in a $5 \% \mathrm{CO}_{2}$ atmosphere. The culture medium for both chambers was Ham's F12 nutrient mixture (Thermo Fisher Scientific, Inc.).

For cell transfection, Th17-polarized $\mathrm{CD}^{+} \mathrm{T}$ cells were cultured at a density of $5 \times 10^{5}$ cells/well in a 96-well plate for $24 \mathrm{~h}$ at room temperature in $5 \% \mathrm{CO}_{2}$ atmosphere. miR-21-5p mimic (sequence, 5'-UAGCUUAUCAGACUGAUGUUGA-3') and the miR-21-5p inhibitor (sequence, 5'-UCAACAUCAGUC UGAUAAGCUA-3') were purchased from Sigma-Aldrich (Merck KGaA). STAT3 was overexpressed using a pcDNA3.1 plasmid (Thermo Fisher Scientific, Inc.). The medium in the 96-well plates was replaced after $24 \mathrm{~h}$, and the cells were transfected with $100 \mathrm{ng}$ miR-21-5p mimic or miR-21-5p inhibitor, and STAT3 using Lipofectamine ${ }^{\circledR} 3000$ (Thermo Fisher Scientific, Inc.), according to the manufacturer's protocol. The cells were harvested $48 \mathrm{~h}$ after transfection and used for subsequent experiments.

Primary melanocytes were isolated from the skin of the 15 patients with VIT by suction blistering (4) and subsequently cultured in the lower chamber containing Hu 16 medium, which was supplemented with $50 \mu \mathrm{g} / \mathrm{ml}$ gentamicin, $20 \mathrm{ng} / \mathrm{ml}$ fibroblast growth factor (Sigma-Aldrich; Merck KGaA), $20 \mu \mathrm{g} / \mathrm{ml}$ isobutylmethylxanthine (Sigma-Aldrich; Merck KGaA) and $10 \mathrm{ng} / \mathrm{ml}$ cholera toxin (Sigma-Aldrich; Merck KGaA), at $37^{\circ} \mathrm{C}$ with $5 \% \mathrm{CO}_{2}$ for $4 \mathrm{~h}$. The cell density in the culture flasks was $5 \times 10^{5}$ cells $/ \mathrm{ml}$.

Subsequently, Th17-polarized $\mathrm{CD}^{+} \mathrm{T}$ cells (in the upper chamber) and primary melanocytes (in the lower chamber) were co-cultured in a 6 -well plate at a density of $1 \times 10^{5}$ cells/well for $72 \mathrm{~h}$ at $37^{\circ} \mathrm{C}$. The cells were harvested for subsequent experiments to detect the survival of primary melanocytes after various treatments. 
Tyrosinase activity detection. Levodopa (L-DOPA) solution (cat. no. 333786; Sigma-Aldrich; Merck KGaA) was used for the detection of tyrosinase activity. Briefly, after co-culturing Th17-polarized CD4 ${ }^{+} \mathrm{T}$ cells obtained from patients with VIT for $72 \mathrm{~h}$, melanocytes were washed once with PBS. Subsequently, cells were pretreated with $90 \mu 11 \%$ Triton X-100 solution at $-80^{\circ} \mathrm{C}$ for $30 \mathrm{~min}$ and allowed to thaw at room temperature. A total of $0.1 \% \mathrm{~L}-\mathrm{DOPA}$ solution $(100 \mu \mathrm{l} /$ well $)$ was then added into cells at $37^{\circ} \mathrm{C}$ for $2 \mathrm{~h}$. OD values at $490 \mathrm{~nm}$ were measured and recorded using a microplate reader (model 680; Bio-Rad Laboratories, Inc.). The tyrosinase activity in each group relative to the control group was calculated as follows: Relative tyrosinase activity $=\left(\mathrm{OD}\right.$ values $_{\text {sample }}-\mathrm{OD}$ values $\left._{\text {control group }}\right) / \mathrm{OD}$ values control group $\mathrm{x} 100$.

Detection of melanin. For melanin detection of melanocytes obtained from the skin of patients with VIT, the supernatant was discarded and the cells were washed once with PBS, and treated with $500 \mu 11 \mathrm{~mol} / \mathrm{l} \mathrm{NaOH}$ diluted into DMSO in a water bath at $70^{\circ} \mathrm{C}$ for $2 \mathrm{~h}$ to dissolve melanin. Subsequently, lysates in the 6-well plate were transferred to a 96-well plate (100 $\mu$ l for each plate). OD values at $405 \mathrm{~nm}$ were measured and recorded using a microplate reader (model 680; Bio-Rad Laboratories, Inc.).

Statistical analysis. The data are expressed as the mean \pm SD $(n \geq 3)$. Statistical analysis was performed using SPSS 20.0 software (IBM Corp.). Statistical significance was analyzed using unpaired Student's t-test to compare control and VIT groups or one-way ANOVA followed by Dunnett's post hoc test for other experiments. $\mathrm{P}<0.05$ was considered to indicate a statistically significant difference.

\section{Results}

Proportion of Treg cells is decreased, but that of Teff cells is increased in $\mathrm{CD}^{+} \mathrm{T}$ cells of patients with VIT. Treg/Teff cell imbalance has been identified in multiple diseases, including skin diseases (11). Therefore, Treg and Teff subset populations in $\mathrm{CD}^{+} \mathrm{T}$ cells from patients with VIT and from normal healthy controls were measured. The proportions of Th17 cells $\left(\mathrm{CD} 4^{+} \mathrm{CD} 8-\mathrm{IL}_{-17^{+}}\right)$and Th22 cells $\left(\mathrm{CD} 4^{+} \mathrm{CD} 8-\mathrm{IL}^{-22}{ }^{+}\right)$ in $\mathrm{CD}^{+} \mathrm{T}$ cells from patients with VIT were significantly increased compared with those from normal individuals $(\mathrm{P}<0.001$; Fig. 1B and $\mathrm{C})$. a significant difference is shown in Fig. $1 \mathrm{~A}$ and $1 \mathrm{D}$, indicating that Th1 $\left(\mathrm{CD} 4^{+} \mathrm{CD} 8-\mathrm{IFN}-\gamma^{+}\right)$and Treg cells $\left(\mathrm{CD} 4^{+} \mathrm{CD} 25^{+} \mathrm{CD} 127^{-}\right)$in patients with VIT were significantly decreased compared with controls $(\mathrm{P}<0.01$; Fig. 1A, P<0.001; Fig. 1D). Therefore, the proportion of Treg cells was decreased, while that of Teff cells was increased in $\mathrm{CD}^{+} \mathrm{T}$ cells of patients with VIT.

Expression levels of the Teff cell cytokines IFN- $\gamma, I L-17 A$ and IL-22 are increased, while those of the Treg cell cellular marker Foxp3 is decreased in patients with VIT. To further explore why Treg cells were decreased but Teff cells were increased in $\mathrm{CD}^{+} \mathrm{T}$ cells of patients with VIT, the expression levels of the Teff cell cytokines IFN- $\gamma$, IL-17A and IL-22, and those of the Treg cell marker Foxp3 were determined using ELISA and RT-qPCR, respectively. The present results indicated that the expression levels of the Teff cytokines IFN- $\gamma$, IL-17A and IL-22 were increased, while Foxp3 expression was decreased in PBMCs of patients with VIT compared with in those of normal healthy controls $(\mathrm{P}<0.001$; Fig. 1E-H).

STAT3 is a target of miR-21-5p, and miR-21-5p expression is downregulated while STAT3 expression is increased in patients with VIT. In order to investigate the role of miR-21-5p in patients with VIT, miR-21-5p expression in PBMCs of patients with VIT and normal healthy controls was detected by RT-qPCR. The results revealed that miR-21-5p expression was significantly decreased in patients with VIT compared with in normal healthy controls ( $\mathrm{P}<0.001$; Fig. 1I).

TargetScan successfully predicted that the target gene of miR-21-5p was STAT3, and its conserved binding sites are shown in Fig. 2A. To further confirm that miR-21-5p could bind to STAT3, a Dual-Luciferase reporter vector containing the STAT3 3'-UTR was built. The Dual-Luciferase reporter assay demonstrated that the relative luciferase activity of the STAT3-WT-mimic (STAT3-WT-M) group was significantly decreased compared with that of the STAT3-WT-mimic control (STAT3-WT-MC) group $(\mathrm{P}<0.001)$, while that of the STAT3-MUT-M group was not affected compared with that of the STAT3-MUT-MC group (Fig. 2B), indicating that STAT3 was the target gene of miR-21-5p.

To determine the role of STAT3 in VIT, the protein and mRNA levels of STAT3 were detected by western blot analysis and RT-qPCR, respectively. As shown in Fig. 2C and D, the relative protein and mRNA levels of STAT3 in patients with VIT were significantly increased compared with in the control group $(\mathrm{P}<0.001)$.

miR-21-5p mimic increases miR-21-5p expression but inhibits STAT3 expression. The association between miR-21-5p and STAT3 in patients with VIT was studied via transfections using a miR-21-5p mimic and STAT3 overexpression plasmids into $\mathrm{CD} 4^{+} \mathrm{T}$ cells. The present results revealed that after miR-21-5p mimic transfection (M+NC), miR-21-5p expression was significantly increased compared with the $\mathrm{MC}+$ negative control $(\mathrm{MC}+\mathrm{NC})$ group $(\mathrm{P}<0.001$; Fig. $3 \mathrm{~A})$, while mRNA and protein levels of STAT3 were significantly decreased $(\mathrm{P}<0.001$; Fig. 3B and C). STAT3 overexpression did not affect miR-21-5p expression levels, whereas miR-21-5p mimic significantly decreased STAT3 expression levels (Fig. 3A-C). In addition, mRNA and protein levels of STAT3 in $\mathrm{CD}^{+} \mathrm{T}$ cells of patients with VIT were significantly increased after STAT3 overexpression $(\mathrm{MC}+\mathrm{STAT} 3 ; \mathrm{P}<0.05$ vs. $\mathrm{MC}+\mathrm{NC}$; Fig. 3B and $\mathrm{C}$ ); however, these were reversed by concomitant miR-21-5p overexpression $(\mathrm{M}+\mathrm{STAT} 3 ; \mathrm{P}<0.01$ vs. MC+STAT3; $\mathrm{P}<0.001$ vs. $\mathrm{M}+\mathrm{NC}$; Fig. $3 \mathrm{~B}$ and $\mathrm{C}$ ).

miR-21-5p overexpression increases the proportion of Treg cells but decreases that of Teff cells by reversing the effects of STAT3. To explore the effects of miR-21-5p and STAT3 on the proportion of Treg/Teff cells in patients with VIT, miR-21-5p was overexpressed in the Th17-polarized CD4 ${ }^{+} \mathrm{T}$ cells, and the proportion of Treg and Teff (Th17 and Th22 cells) cell subsets in $\mathrm{CD}^{+}{ }^{+} \mathrm{T}$ cells was measured. Flow cytometry assays demonstrated that after miR-21-5p overexpression, the proportion of Teff cells (Th17 and Th22 cells) in CD4 $4^{+} \mathrm{T}$ cells was 
A

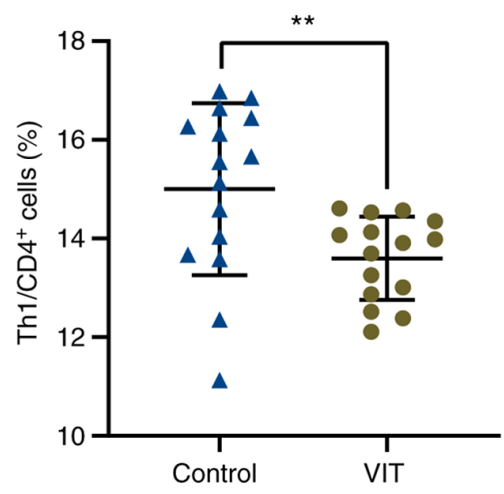

C

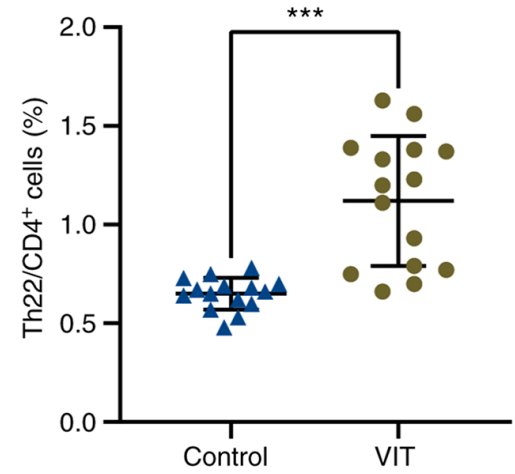

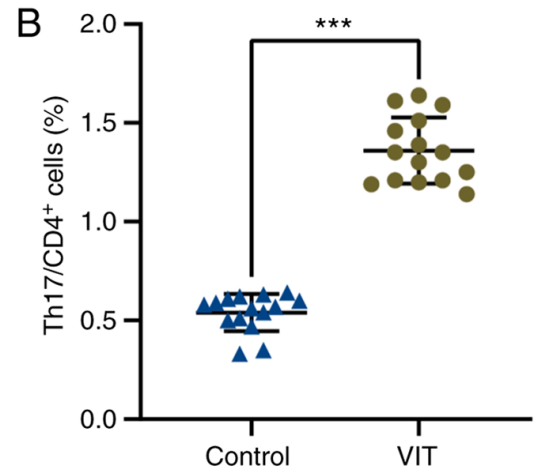

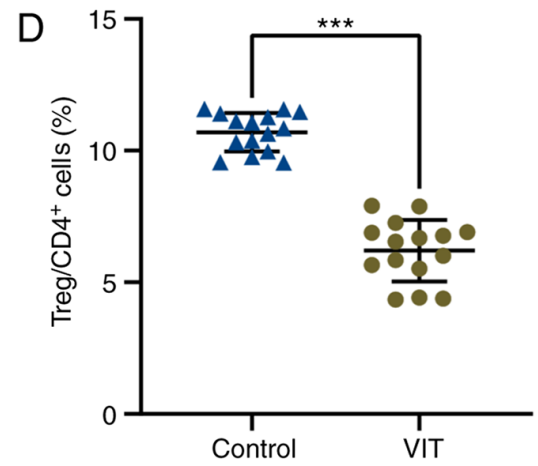

$\mathrm{E}$

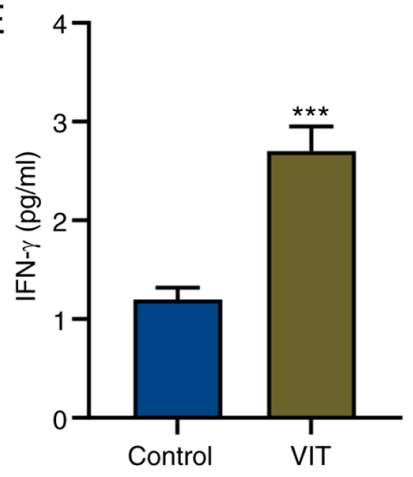

$\mathrm{F}$

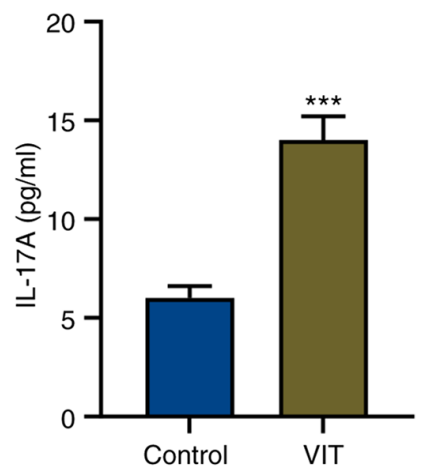

G

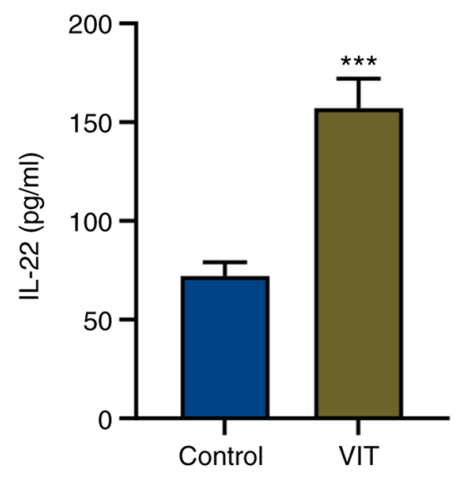

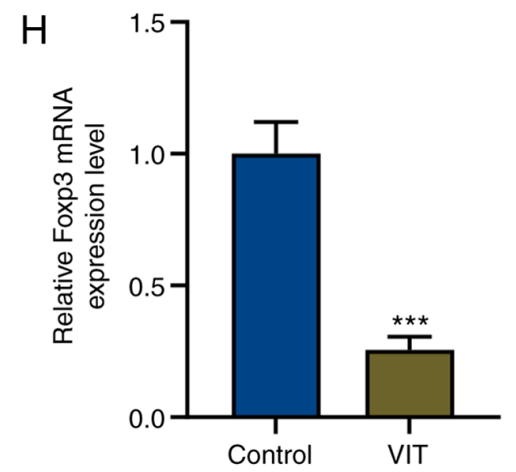

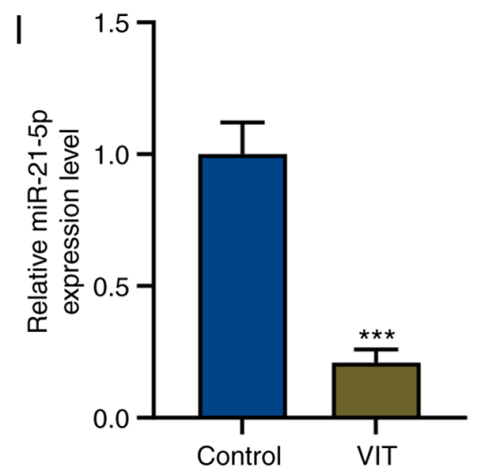

Figure 1. Imbalance of T effector/Treg cells and dysregulation of miR-21-5p in patients with VIT. Percentages of (A) Th1, (B) Th17, (C) Th22 and (D) Treg cells in $\mathrm{CD} 4^{+} \mathrm{T}$ cells of peripheral blood mononuclear cells in patients with VIT and healthy controls ( $\mathrm{n}=15$ for each group) were measured via flow cytometry. Protein levels of (E) IFN- $\gamma,($ F) IL-17A and (G) IL-22 in the peripheral blood of patients with VIT and healthy controls were measured via enzyme-linked immunosorbent assay. Relative expression levels of (H) Foxp3 and (I) miR-21-5p in the peripheral blood of patients with VIT and healthy controls were measured via reverse transcription-quantitative PCR. GAPDH and U6 were used as the internal controls, respectively. ${ }^{* *} \mathrm{P}<0.01$; ${ }^{* * *} \mathrm{P}<0.001$. VIT, vitiligo; Th, T helper; IFN, interferon; IL, interleukin; miR, microRNA; Treg cells, regulatory T cells.

decreased, but that of Treg cells was increased compared with the $\mathrm{MC}+\mathrm{NC}$ group $(\mathrm{P}<0.01$; Fig. 4A-C). STAT3 overexpression resulted in the opposite results, with increased Teff cells and decreased Treg cells $(\mathrm{P}<0.01)$; however, this was partially reversed by miR-21-5p overexpression ( $\mathrm{P}<0.01$ vs. MC+STAT3 and vs. M+NC; Fig. 4A-C). 
A

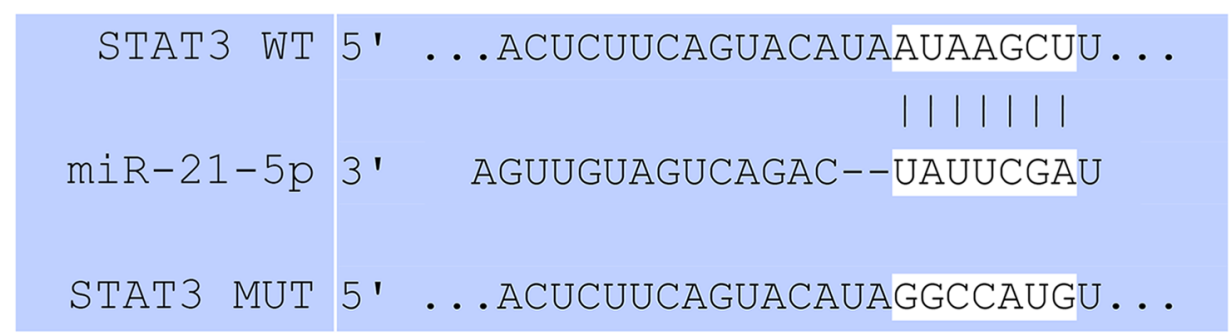

$\mathrm{B}$
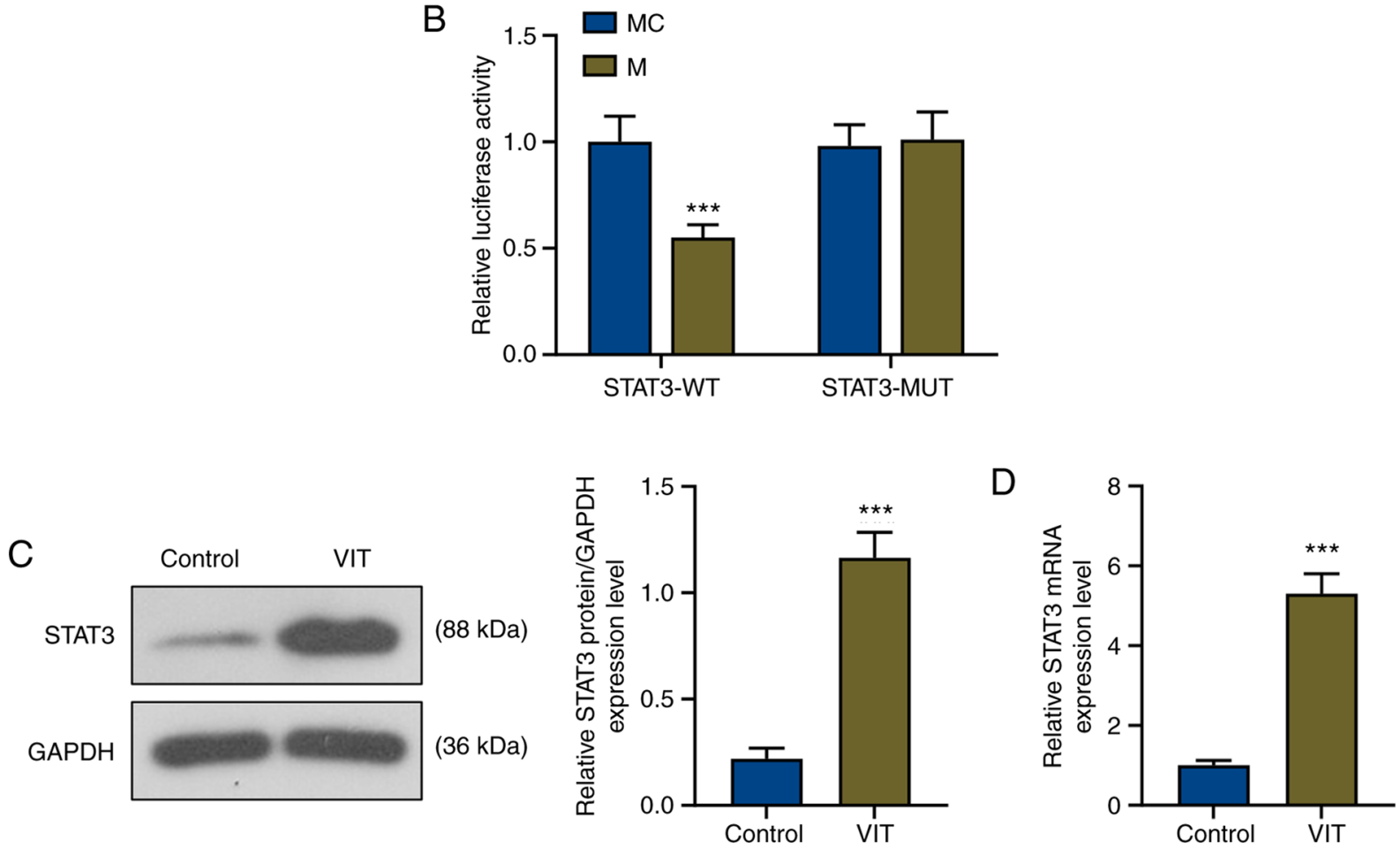

Figure 2. STAT3 is a target of miR-21-5p. (A) Binding sites of the WT and MUT STAT3 sequences to miR-21-5p were predicted using TargetScan. (B) Dual-Luciferase reporter assay confirmed that STAT3 was a target gene of miR-21-5p. ${ }^{* * *} \mathrm{P}<0.001 \mathrm{vs}$. MC. (C) Relative STAT3 protein expression in the control and VIT groups was detected via western blot analysis. GAPDH was used as the internal control. (D) Relative STAT3 mRNA expression in the control and VIT groups was detected via reverse transcription-quantitative PCR. GAPDH was used as the internal control. ${ }^{* * *} \mathrm{P}<0.001$ vs. control. miR, microRNA; M, miR-21-5p mimic; MC, mimic control; WT, wild-type; MUT, mutant; VIT, vitiligo.

miR-21-5p overexpression decreases the expression levels of $I L-17 A$ and IL-22 cytokines in Teff cells but increases Foxp3 expression in Treg cells by reversing the effects of STAT3. Subsequently, expression levels of the Teff cell cytokines IL-17A and IL-22, and those of the Treg cell marker Foxp3 in $\mathrm{CD}^{+} \mathrm{T}$ cells of patients with VIT and normal healthy controls were detected via ELISA and RT-qPCR, respectively. The present results revealed that IL-17A and IL-22 expression levels were decreased, while Foxp3 expression was significantly increased after miR-21-5p overexpression compared with the $\mathrm{MC}+\mathrm{NC}$ group $(\mathrm{P}<0.01$ and $\mathrm{P}<0.001$; Fig. 4D-F). However, after STAT3 overexpression, IL-17A and IL-22 expression levels were increased compared with the $\mathrm{MC}+\mathrm{NC}$ group $(\mathrm{P}<0.05$; Fig. 4D-E). Furthermore, miR-21-5p overexpression reversed the effects of STAT3 overexpression on the expression levels of Teff cell cytokines and the Treg cell marker $(\mathrm{P}<0.01$ vs. $\mathrm{MC}+\mathrm{STAT} 3 ; \mathrm{P}<0.01$ and $\mathrm{P}<0.001$ vs. M+NC; Fig. 4D-F).

miR-21-5p/STAT3 axis in Th17-polarized $C D 4^{+} \mathrm{T}$ cells regulates the apoptosis of melanocytes. In order to further determine the effects of the miR-21-5p/STAT3 axis on Th17-polarized $\mathrm{CD}^{+} \mathrm{T}$ cells in melanocytes protection, the apoptosis of melanocytes after co-culture with pretreated $\mathrm{CD} 4^{+}$ $\mathrm{T}$ cells was examined via flow cytometry. It was observed that the apoptosis of melanocytes was decreased by miR-21-5p overexpression in Th17-polarized CD4 ${ }^{+} \mathrm{T}$ cells $(\mathrm{P}<0.001$ vs. $\mathrm{MC}+\mathrm{NC})$, but increased after STAT3 overexpression $(\mathrm{P}<0.05$ vs. MC+NC), suggesting that STAT3 overexpression in $\mathrm{CD} 4^{+}$ $\mathrm{T}$ cells could induce apoptosis of melanocytes (Fig. 5A). In addition, miR-21-5p overexpression in Th17-polarized CD4 ${ }^{+}$ $\mathrm{T}$ cells reversed the effects of STAT3 overexpression on the apoptosis of melanocytes $(\mathrm{P}<0.01$ vs. MC+STAT3; $\mathrm{P}<0.001$ vs. M+NC; Fig. 5A).

miR-21-5p/STAT3 axis in Th17-polarized $C D 4^{+} T$ cells regulates the release of $I L-17 A$ and $I L-22$ cytokines. After co-culture of $\mathrm{CD}^{+} \mathrm{T}$ cells and melanocytes, the levels of released cytokines (IL-17A and IL-22) were measured via ELISA, and it was observed that after miR-21-5p overexpression in Th17-polarized $\mathrm{CD}^{+}{ }^{+} \mathrm{T}$ cells, the expression levels of IL-17A and IL-22 in the lower chamber were decreased 

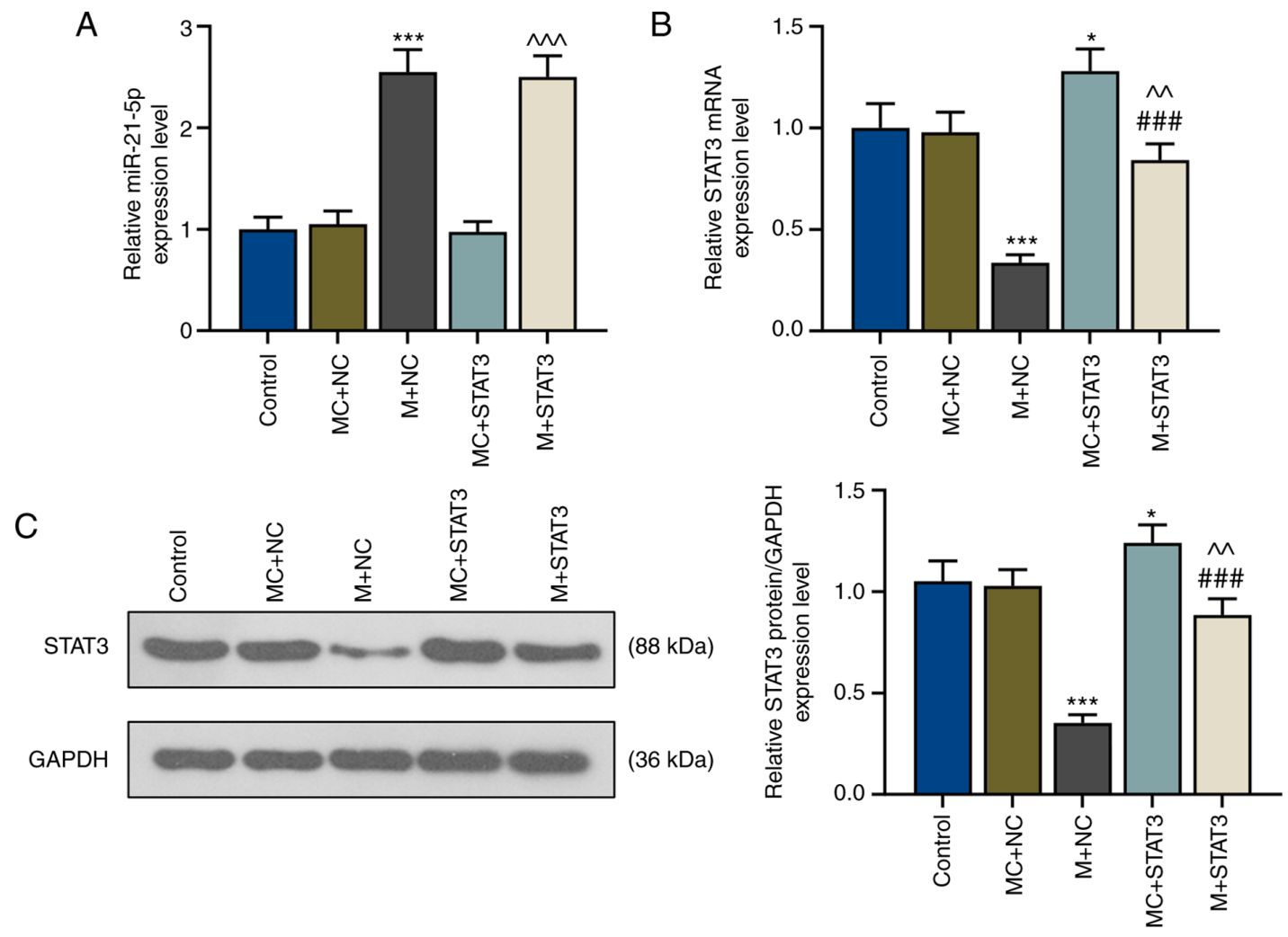

Figure 3. miR-21-5p mimic inhibits STAT3 expression in T helper 17-polarized CD4 ${ }^{+} \mathrm{T}$ cells of patients with vitiligo. (A) Relative expression levels of (A) miR-21-5p and (B) STAT3 of the control, MC+NC, M+NC, MC+STAT3 and M+STAT3 groups were measured via reverse transcription-quantitative PCR. U6 and GAPDH were used as internal controls, respectively. ${ }^{*} \mathrm{P}<0.05$ and ${ }^{* * * *} \mathrm{P}<0.001$ vs. MC+NC; ${ }^{\wedge \wedge} \mathrm{P}<0.01$ and ${ }^{\wedge \wedge} \mathrm{P}<0.001$ vs. MC+STAT3; ${ }^{\# \# "} \mathrm{P}<0.001$ vs. $\mathrm{M}+\mathrm{NC}$. (C) Relative STAT3 protein expression of the control, MC+NC, M+NC, MC+STAT3 and M+STAT3 groups were measured via western blot analysis. GAPDH was used as the internal control. ${ }^{*} \mathrm{P}<0.05$ vs. MC+NC; ${ }^{* * *} \mathrm{P}<0.001$ vs. $\mathrm{MC}+\mathrm{NC} ;{ }^{\# \#} \mathrm{P}<0.001$ vs. M+NC; ${ }^{\wedge} \mathrm{P}<0.01$ vs. MC+STAT3. miR, microRNA; M, miR-21-5p mimic; MC, mimic control; NC, negative control.

A
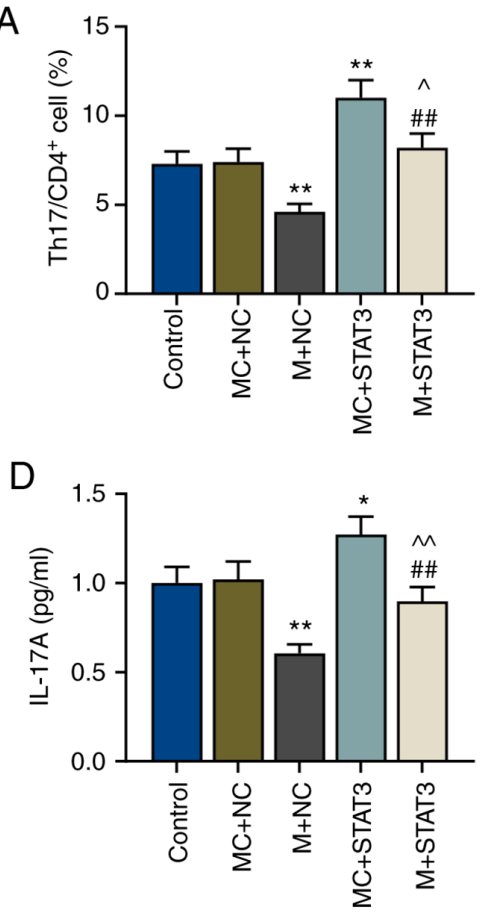

$\mathrm{B}$

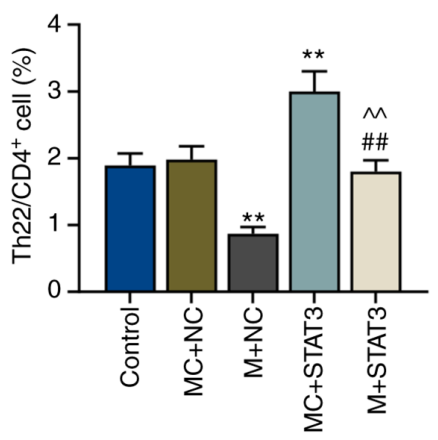

$\mathrm{E}$

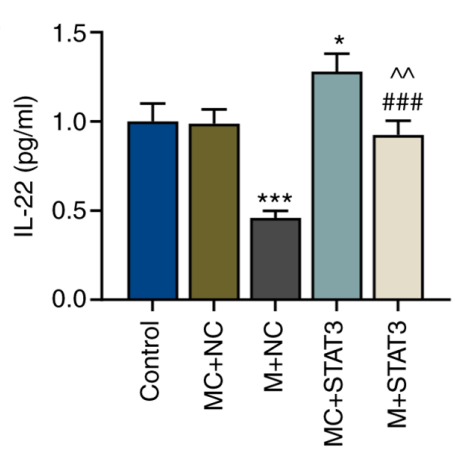

$\mathrm{C}$

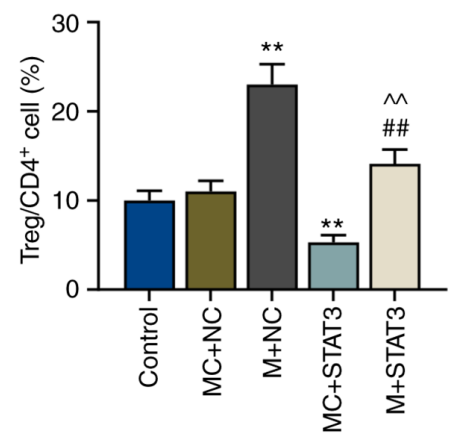

$\mathrm{F}$

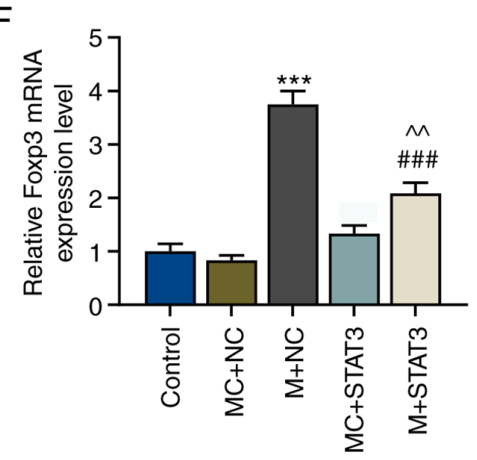

Figure 4. miR-21-5p overexpression regulates T effector/Treg cell balance via STAT3. Percentages of (A) Th17, (B) Th22 and (C) Treg cells in CD4+ ${ }^{+}$cells of the control, MC+NC, M+NC, MC+STAT3 and M+STAT3 groups were measured via flow cytometry. Protein levels of (D) IL-17A and (E) IL-22 of T cells in the control, MC+NC, M+NC, MC+STAT3 and M+STAT3 groups were measured via enzyme-linked immunosorbent assay. (F) Relative Foxp3 expression in the control, MC+NC, M+NC, MC+STAT3 and M+STAT3 groups were measured via reverse transcription-quantitative PCR. GAPDH was used as the internal control. ${ }^{*} \mathrm{P}<0.05,{ }^{* * *} \mathrm{P}<0.01$ and ${ }^{* * * *} \mathrm{P}<0.001$ vs. MC+NC; ${ }^{\wedge} \mathrm{P}<0.05$ and ${ }^{\wedge \wedge} \mathrm{P}<0.01$ vs. MC+STAT3; ${ }^{\# \#} \mathrm{P}<0.01$ and ${ }^{\# \# \#} \mathrm{P}<0.001$ vs. M+NC. Th, T helper; IL, interleukin; miR, microRNA; Treg cells, regulatory T cells; M, miR-21-5p mimic; MC, mimic control; NC, negative control. 

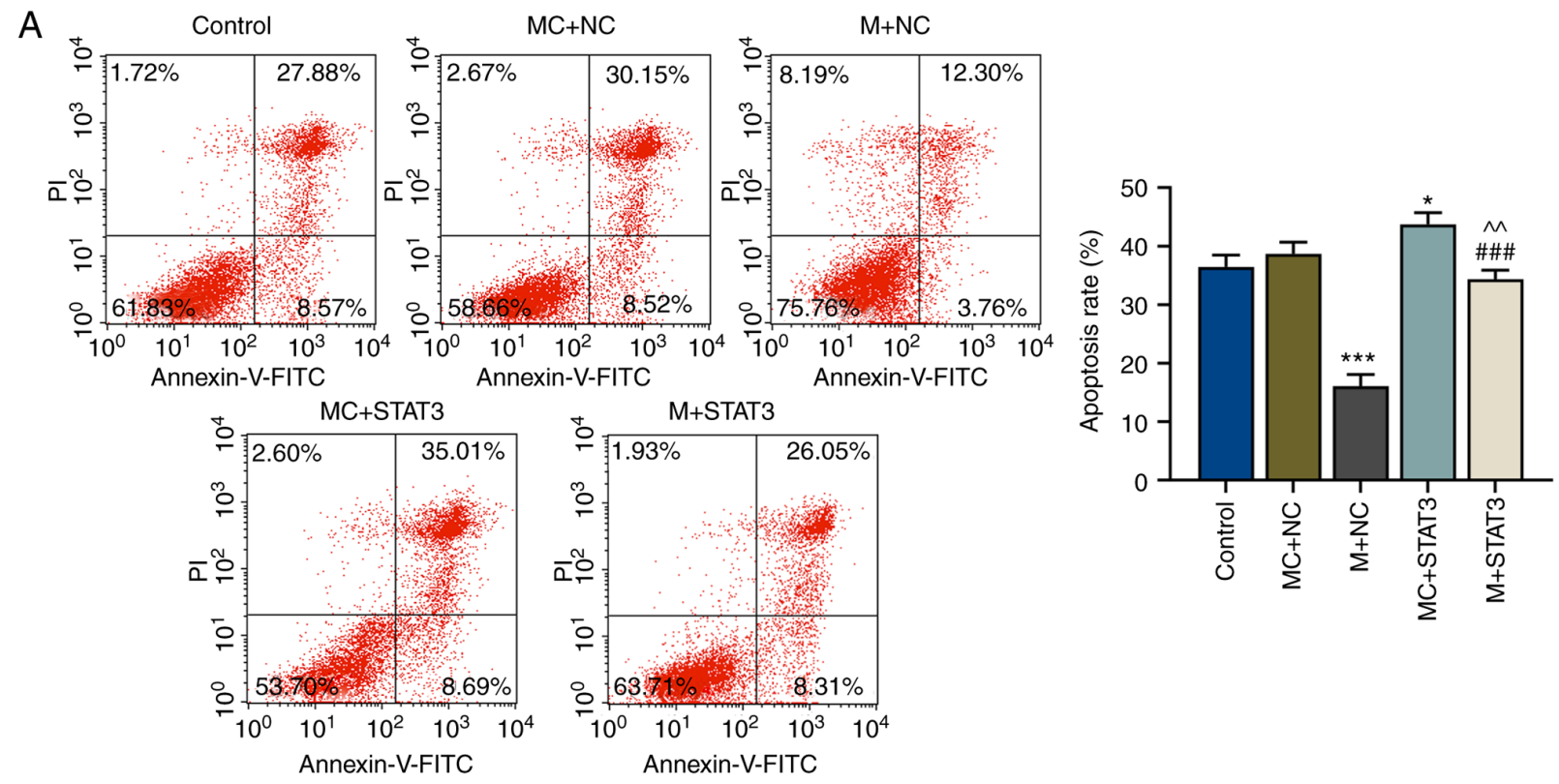

B
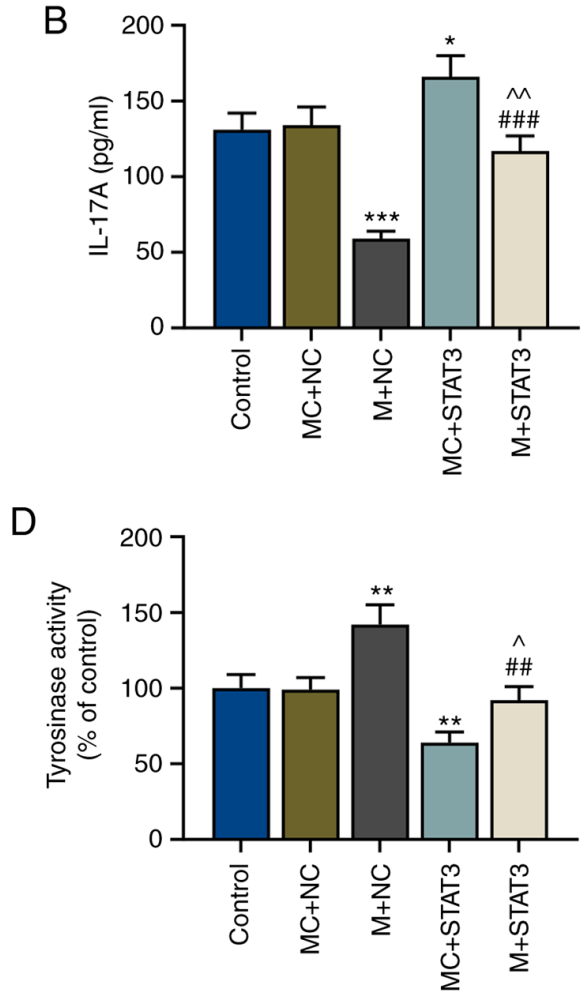

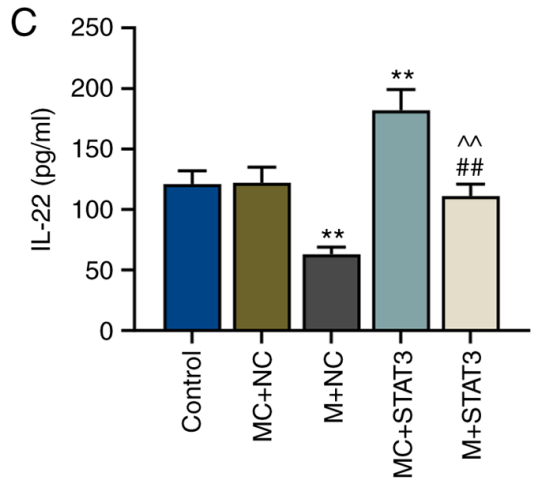

E

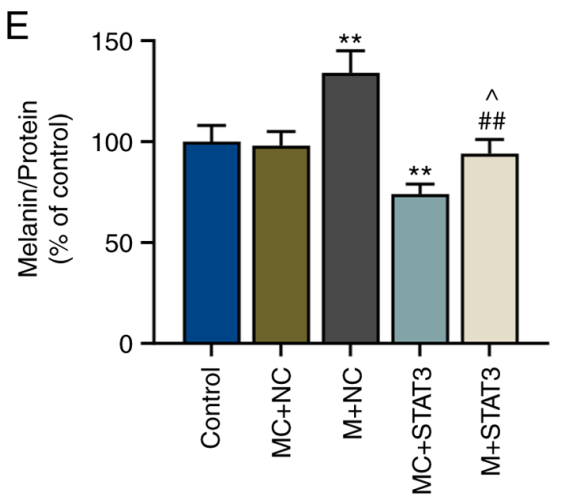

Figure 5. miR-21-5p overexpression may protect melanocytes via regulating $\mathrm{T}$ effector/regulatory $\mathrm{T}$ cell balance through STAT3. (A) Apoptosis rates of melanocytes in the control, MC+NC, M+NC, MC+STAT3 and M+STAT3 groups were measured via flow cytometry. Protein levels of (B) IL-17A and (C) IL-22 in the lower chamber of Transwell inserts after co-culture of melanocytes and Th17-polarized CD4 ${ }^{+} \mathrm{T}$ cells in the control, MC+NC, M+NC, MC+STAT3 and M+STAT3 groups was measured via enzyme-linked immunosorbent assay. (D) Tyrosinase activity and (E) relative melanin content in melanocytes in the control, MC+NC, M+NC, MC+STAT3 and M+STAT3 groups were measured using a microplate reader. ${ }^{*} \mathrm{P}<0.05,{ }^{* *} \mathrm{P}<0.01$ and ${ }^{* * * *} \mathrm{P}<0.001 \mathrm{vs}$. MC+NC; ${ }^{\wedge} \mathrm{P}<0.05$ and ${ }^{\wedge} \mathrm{P}<0.01$ vs. MC+STAT3; ${ }^{\# \#} \mathrm{P}<0.01$ and ${ }^{\# \# t} \mathrm{P}<0.001$ vs. M+NC. Th, T helper; IL, interleukin; miR, microRNA; M, miR-21-5p mimic; MC, mimic control; $\mathrm{NC}$, negative control.

compared with the $\mathrm{MC}+\mathrm{NC}$ group $(\mathrm{P}<0.001$ and $\mathrm{P}<0.01$; Fig. 5B and $\mathrm{C}$, respectively); however, these were reversed by STAT3 overexpression $(\mathrm{P}<0.05$ and $\mathrm{P}<0.01$; Fig. 5B and $\mathrm{C}$, respectively). miR-21-5p overexpression in Th17-polarized $\mathrm{CD}^{+}{ }^{+} \mathrm{T}$ reversed the effects of STAT3 overexpression on the release of IL-17A and IL-22 ( $\mathrm{P}<0.01$ vs. MC+STAT3; $\mathrm{P}<0.001$ and $\mathrm{P}<0.01$ vs. $\mathrm{M}+\mathrm{NC}$; Fig. $5 \mathrm{~B}$ and $\mathrm{C}$, respectively).
miR-21-5p/STAT3 axis in $C D 4^{+} T$ cells regulates tyrosinase activity and melanin synthesis. The effects of the miR-21-5p/STAT3 axis in CD4 ${ }^{+} \mathrm{T}$ cells on tyrosinase activity and melanin synthesis of melanocytes were explored. Tyrosinase activity and melanin content in melanocytes were detected using a microplate reader. As shown in Fig. 5D and E, tyrosinase activity and melanin content of melanocytes were 


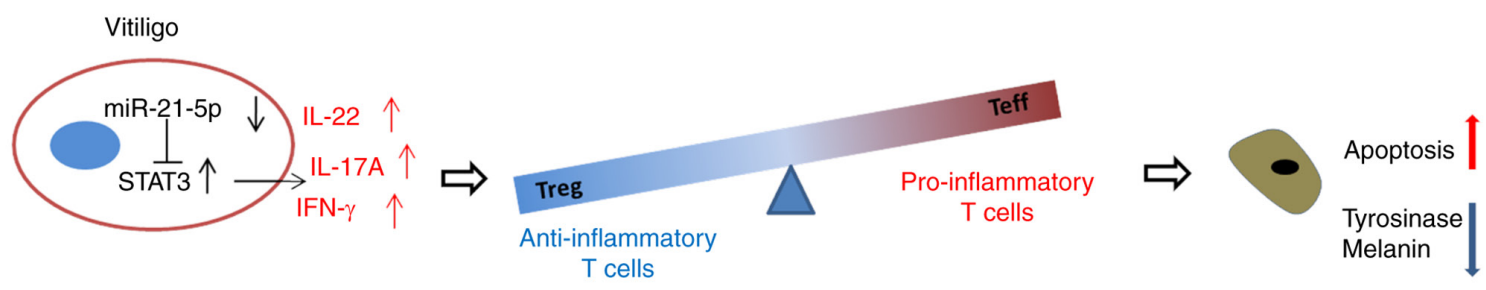

miR-21-5p mimic treatment
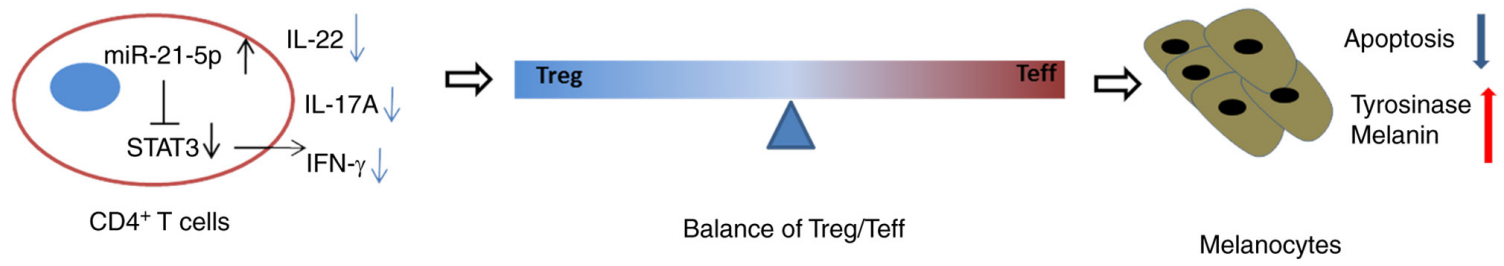

Figure 6. Potential mechanism of the interaction between miR-21-5p and STAT3 in vitiligo. Low miR-21-5p expression may induce the differentiation of $\mathrm{CD}^{+} \mathrm{T}$ cells towards Teff cells, causing a pro-inflammatory response and thereby increasing apoptosis in melanocytes. However, miR-21-5p mimic treatment promoted the balance of Treg/Teff cells and thereby had a benefit on the survival of melanocytes. Th, T helper; IFN, interferon; IL, interleukin; miR, microRNA; Treg/Teff cells, regulatory T/effector T cells.

increased after miR-21-5p overexpression in Th17-polarized $\mathrm{CD} 4^{+} \mathrm{T}(\mathrm{P}<0.01$ vs. $\mathrm{MC}+\mathrm{NC})$, but STAT3 overexpression in Th17-polarized $\mathrm{CD} 4^{+} \mathrm{T}$ resulted in opposite results, with both tyrosinase activity and melanin synthesis being decreased compared with the $\mathrm{MC}+\mathrm{NC}$ group $(\mathrm{P}<0.01)$ (Fig. 5D and $\mathrm{E})$. Furthermore, miR-21-5p overexpression in Th17-polarized $\mathrm{CD} 4^{+} \mathrm{T}$ cells reversed the effects of STAT3 overexpression on tyrosinase activity and melanin content of melanocytes $(\mathrm{P}<0.05$ vs. MC+STAT3; $\mathrm{P}<0.01$ vs. M+NC; Fig. $5 \mathrm{D}$ and $\mathrm{E})$. Finally, a potential mechanism has been constructed (Fig. 6), which indicated that miR-21-5p protected melanocytes via targeting STAT3 and modulating the Treg/Teff balance to alleviate VIT.

\section{Discussion}

The balance between Treg and Teff cells has been the focus of the pathological examination of numerous autoimmune disorders, such as uveitis, scleroderma and rheumatoid arthritis $(9,10,22)$. Treg cells, which are a subset of T cells, serve a vital role in peripheral immune tolerance maintenance (23), and Teff cells have the function of regulating immunity and inflammation (9). Decreased activity of Treg cells enhances the activity of Teff cells, particularly the activity of Th17 cells (24). The present study observed an imbalance between Treg and Teff cells in $\mathrm{CD} 4^{+} \mathrm{T}$ cells in patients with VIT; specifically, the proportion of Teff cells was increased but that of Treg cells was decreased in $\mathrm{CD} 4^{+} \mathrm{T}$ cells of patients with VIT compared with those of healthy controls, with the expression levels of the Treg cellular marker Foxp3 being decreased and the secretion of Teff cell cytokines (IFN- $\gamma$, IL-17A and IL-22) being increased. It was noted that the proportion of Th22 cells in patients with VIT had a higher SD compared with other T-cell subtypes; this high SD may be due to individual differences among patients with VIT, although there is currently no evidence to support this hypothesis.

miRNAs regulate the balance of Treg/Teff cells (25), consistent with the findings of the present study, in which miR-21-5p expression in patients with VIT was decreased compared with in healthy individuals. Therefore, a miR-21-5p mimic was transfected into Th17-polarized $\mathrm{CD}^{+} \mathrm{T}$ cells to overexpress miR-21-5p and study its potential effects. The present data revealed that miR-21-5p overexpression regulated the Treg/Teff balance in $\mathrm{CD}^{+} \mathrm{T}$ cells, which was consistent with a previous study suggesting that miR-21-5p may regulate Treg/Teff balance in CD4 ${ }^{+} \mathrm{T}$ cells (15). Therefore, miR-21-5p may be a potential regulator of Treg/Teff balance.

miRNAs target mRNAs to regulate their expression and functions (26). A previous study has demonstrated that STAT3 can bind to the promoter of the miR-21 gene and thereby enhances the expression levels of pre-miR-21 and mature miR-21 in $\mathrm{CD}^{+} \mathrm{T}$ cells induced upon IL-21 stimulation in Sezary syndrome (27). Similar results have been observed in cellular transformation in which STAT3 directly activates the transcription of miR-21 (28). By contrast, the present study indicated that miR-21-5p could regulate STAT3 expression in $\mathrm{CD} 4^{+} \mathrm{T}$ cells. Therefore, it is inferred that a feedback loop may exist between STAT3 and miR-21 in $\mathrm{CD}^{+} \mathrm{T}$ cells, which should be further explored in future studies.

STAT3 may be modulated by arsenic trioxide in treatment-naïve patients with rheumatoid arthritis and may improve the Treg/Teff balance (29). STAT3 has been detected in VIT pathogenesis (30), but the association between STAT3 modulation and Treg/Teff balance in VIT is less explored. The present study demonstrated that STAT3 was the target of miR-21-5p and that its expression in patients with VIT was increased compared with in normal controls, causing an imbalance between Treg and Teff cells; however, this effect was reversed by miR-21-5p overexpression. Nevertheless, the mechanism through which miR-21-5p/STAT3 regulates the Treg/Teff balance in $\mathrm{CD}^{+} \mathrm{T}$ cells requires further elucidation.

Melanocytes serve an important role in VIT pathogenesis, and interaction between intrinsic and extrinsic melanocyte defects may be a key factor causing the onset of VIT (31). Therefore, protection of melanocytes may be a possible clinical method for VIT treatment. Zhou et al (32) revealed that IL-10 may contribute to the survival of primary melanocytes via the activation of the STAT3 and PI3K/Akt/NF-KB signaling 
pathways. The present study demonstrated that miR-21-5p overexpression indirectly ensured the survival of melanocytes with increasing tyrosinase activity and melanin synthesis via regulating the Treg/Teff balance, and that the effect of miR-21-5p overexpression was reversed by overexpression of its target gene, STAT3.

Additionally, it should be noted that there are some limitations in the present study, such as that only cellular assays were performed and that the analysis of $\mathrm{CD} 4^{+} \mathrm{T}$ cells from patients with VIT were preliminary. Therefore, more comprehensive experiments are required to confirm the effects of miR-21-5p in the development and progression of VIT using an animal model.

In conclusion, the present study identified a potential novel role for miR-21-5p in patients with VIT involving the protection of melanocytes via regulating the Treg/Teff balance. During this process, STAT3 may be a crucial target gene. Therefore, miR-21-5p may be used as a potential therapeutic target for treating VIT.

\section{Acknowledgements}

Not applicable.

\section{Funding}

No funding was received.

\section{Availability of data and materials}

The datasets generated and/or analyzed during the current study are available from the corresponding author on reasonable request.

\section{Authors' contributions}

$\mathrm{JH}$ substantially contributed to the conception and design of the present study. TL, FL, XS and XH were involved in the data acquisition, analysis and interpretation, and in drafting and critically revising the manuscript for important intellectual content. All authors have read and approved the final manuscript.

\section{Ethics approval and consent to participate}

All experiments performed in the present study involving human participants were in accordance with the ethical standards of the institutional and/or national research committee and with the 1964 Declaration of Helsinki and its later amendments or comparable ethical standards. The present study was approved by the Ethics Committee of Dezhou People's Hospital (approval no. PFK20181006; Dezhou, China). All participants provided written informed consent.

\section{Patient consent for publication}

Not applicable.

\section{Competing interests}

The authors declare that they have no competing interests.

\section{References}

1. Ezzedine K, Eleftheriadou V, Whitton M and van Geel N: Vitiligo: Lancet 386: 74-84, 2015.

2. Lai YC, Yew YW, Kennedy C and Schwartz RA: Vitiligo and depression: A systematic review and meta-analysis of observational studies. Br J Dermatol 177: 708-718, 2017.

3. Xie H, Zhou F, Liu L, Zhu G, Li Q, Li C and Gao T: Vitiligo: How do oxidative stress-induced autoantigens trigger autoimmunity? J Dermatolo Sci 81: 3-9, 2016.

4. Lv M, Li Z, Liu J, Lin F, Zhang Q, Li Z, Wang Y, Wang K and $\mathrm{Xu}$ Y: MicroRNA155 inhibits the proliferation of $\mathrm{CD}^{+} \mathrm{T}$ cells via upregulating regulatory T cells in vitiligo. Mol Med Rep 20: 3617-3624, 2019.

5. Lin JY and Fisher DE: Melanocyte biology and skin pigmentation. Nature 445: 843-850, 2007.

6. Patel S, Rauf A, Khan H, Meher BR and Hassan SSU: A holistic review on the autoimmune disease vitiligo with emphasis on the causal factors. Biomed Pharmacother 92: 501-508, 2017.

7. Frisoli ML and Harris JE: Vitiligo: Mechanistic insights lead to novel treatments. J Allergy Clin Immunol 140: 654-662, 2017.

8. Sabat R, Wolk K, Loyal L, Docke WD and Ghoreschi K: T cell pathology in skin inflammation. Semin Immunopathol 41: 359-377, 2019.

9. Zhu W, Chen X, Yu J, Xiao Y, Li Y, Wan S, Su W and Liang D: Baicalin modulates the Treg/Teff balance to alleviate uveitis by activating the aryl hydrocarbon receptor. Biochem Pharmacol 154: 18-27, 2018.

10. Wang Y, Zhang S, Liang Z, Feng M, Zhao X, Qin K, Gao C, $\mathrm{Li}$ X, Guo H and Luo J: Metformin attenuates bleomycin-induced scleroderma by regulating the balance of Treg/Teff cells and reducing spleen germinal center formation. Mol Immunol 114: 72-80, 2019.

11. Kalekar LA and Rosenblum MD: Regulatory T cells in inflammatory skin disease: From mice to humans. Int Immunol 31: 457-463, 2019.

12. De Santis G, Ferracin M, Biondani A, Caniatti L, Rosaria Tola M, Castellazzi M, Zagatti B, Battistini L, Borsellino G, Fainardi E, et al: Altered miRNA expression in $\mathrm{T}$ regulatory cells in course of multiple sclerosis. J Neuroimmunol 226: 165-171, 2010.

13. Mansuri MS, Singh M and Begum R: miRNA signatures and transcriptional regulation of their target genes in vitiligo. J Dermatol Sci 84: 50-58, 2016.

14. Yan S, Shi J, Sun D and Lyu L: Current insight into the roles of microRNA in vitiligo. Mol Biol Rep 47: 3211-3219, 2020.

15. Zheng X, Dong L, Wang K, Zou H, Zhao S, Wang Y and Wang G: MiR-21 participates in the PD-1/PD-L1 pathway-mediated imbalance of Th17/Treg cells in patients after gastric cancer resection. Ann Surg Oncol 26: 884-893, 2019.

16. Dong L, Wang X, Tan J, Li H, Qian W, Chen J, Chen Q, Wang J, $\mathrm{Xu}$ W, Tao C and Wang S: Decreased expression of microRNA-21 correlates with the imbalance of Th17 and Treg cells in patients with rheumatoid arthritis. J Cell Mol Med 18: 2213-2224, 2014.

17. Rouas R, Fayyad-Kazan H, El Zein N, Lewalle P, Rothé F, Simion A, Akl H, Mourtada M, El Rifai M, Burny A, et al: Human natural Treg microRNA signature: Role of microRNA-31 and microRNA-21 in FOXP3 expression. Eur J Immunol 39: 1608-1618, 2009.

18. Tscherner A, Brown AC, Stalker L, Kao J, Dufort I, Sirard MA and LaMarre J: STAT3 signaling stimulates miR-21 expression in bovine cumulus cells during in vitro oocyte maturation. Sci Rep 8: 11527, 2018.

19. Fuss IJ, Kanof ME, Smith PD and Zola H: Isolation of whole mononuclear cells from peripheral blood and cord blood. Curr Protoc Immunol Chapter 7: Unit7.1, 2009.

20. Livak KJ and Schmittgen TD: Analysis of relative gene expression data using real-time quantitative PCR and the 2(-Delta Delta C(T)) method. Methods 25: 402-408, 2001.

21. Banerjee K, Pru C, Pru JK and Resat H: STAT3 knockdown induces tumor formation by MDA-MB-231 cells. Clin Oncol Res 1: 10.31487/j.COR.2018.10.002, 2018

22. Huang Z, Yang B, Shi Y, Cai B, Li Y, Feng W, Fu Y, Luo L and Wang L: Anti-TNF- $\alpha$ therapy improves Treg and suppresses Teff in patients with rheumatoid arthritis. Cell Immunol 279: 25-29, 2012.

23. Yang WY, Shao Y, Lopez-Pastrana J, Mai J, Wang H and Yang XF: Pathological conditions re-shape physiological tregs into pathological tregs. Burns Trauma 3: 1, 2015. 
24. Saini C, Siddiqui A, Ramesh V and Nath I: Leprosy reactions show increased Th17 cell activity and reduced FOXP $3^{+}$Tregs with concomitant decrease in TGF- $\beta$ and increase in IL-6. PLoS Negl Trop Dis 10: e0004592, 2016.

25. Liu C, Yang H, Shi W, Wang T and Ruan Q: MicroRNA-mediated regulation of $\mathrm{T}$ helper type 17/regulatory T-cell balance in autoimmune disease. Immunology 155: 427-434, 2018.

26. Catalanotto C, Cogoni $\mathrm{C}$ and Zardo G: MicroRNA in control of gene expression: An overview of nuclear functions. Int J Mol Sci 17: 1712, 2016.

27. van der Fits L, van Kester MS, Qin Y, Out-Luiting JJ, Smit F, Zoutman WH, Willemze R, Tensen CP and Vermeer MH: MicroRNA-21 expression in CD $4^{+} \mathrm{T}$ cells is regulated by STAT3 and is pathologically involved in Sezary syndrome. J Invest Dermatol 131: 762-768, 2011.

28. Iliopoulos D, Jaeger SA, Hirsch HA, Bulyk ML and Struhl K: STAT3 activation of miR-21 and miR-181b-1 via PTEN and CYLD are part of the epigenetic switch linking inflammation to cancer. Mol Cell 39: 493-506, 2010.
29. Almasi-Nasrabadi M, Amoli MM, Robati RM, Rajabi F, Ghalamkarpour F and Gauthier Y: CDH1 and DDR1 common variants confer risk to vitiligo and autoimmune comorbidities. Gene 700: 17-22, 2019.

30. Samaka RM, Basha MA and Menesy D: Role of Janus kinase 1 and signal transducer and activator of transcription 3 in vitiligo. Clin Cosmet Investig Dermatol 12: 469-480, 2019.

31. Rashighi M and Harris JE: Vitiligo pathogenesis and emerging treatments. Dermatol Clin 35: 257-265, 2017

32. Zhou J, Ling J, Song J, Wang Y, Feng B and Ping F: Interleukin 10 protects primary melanocyte by activation of Stat-3 and $\mathrm{PI} 3 \mathrm{~K} / \mathrm{Akt} / \mathrm{NF}-\kappa \mathrm{B}$ signaling pathways. Cytokine 83: 275-281, 2016.

This work is licensed under a Creative Commons Attribution-NonCommercial-NoDerivatives 4.0 International (CC BY-NC-ND 4.0) License. 